\title{
Service Quality Effect of Satisfaction and the Impact on Tourism Loyalty (The Tourism Survey in Integrated tourist area of Trans Studio Bandung)
}

\author{
Dr. Sukmadi, HeruRiyadi, Ananta Budhi Danurdara and Anwari Masatip
}

\begin{abstract}
This study aims to identify and analyze (1) the effect of service quality and tourist satisfaction, (2) the effect of service quality on loyalty Tourists, (3) the effect of satisfaction on loyalty Tourists in Tourism Regions Integrated Trans Studio Bandung. The research method used is explanatory research, which would explain the causal relationship between the independent variable on the dependent variable through hypothesis testing. In this study the data used in the form of primary data obtained the results of questionnaires. While the analysis of the data used in the form of descriptive analysis and analysis of simple and multiple linear regressions.

Based on the results of this research is that (1) quality of service and a significant positive effect on tourist satisfaction in integrated tourism Trans Studio Bandung. That is good service quality can increase the confidence rating on the quality of services offered, with the optimum service quality satisfaction of tourists will increase by itself, (2) quality of service and a significant positive effect on loyalty Tourists in integrated tourism Trans Studio Bandung. This means that service quality also has a strategic role in shaping wisatawa loyalty. A tourist will be loyal to a tourist attraction if tourism is well able to meet their needs, (3) Tourist satisfaction and a significant positive effect on loyalty Tourists in integrated tourism Trans Studio Bandung. This means that if a tourist was satisfied with the services received, the loyalty will be formed.
\end{abstract}

Key Words: Quality of Service, Guest Satisfaction, Loyalty Tourist.

\section{Introduction}

Bandung is the biggest metropolitan city in West Java and the capital of the province. The city is located $140 \mathrm{~km}$ southeast of Jakarta, and is the third largest city in Indonesia after Jakarta and Surabaya by population. Bandung has many tourist attractions which can be visited ranging from nature tourism, culinary tourism, historical attractions, tourist children, shopping or the tourist shopping and integrated. One of the integrated tourism area which is the most famous Trans Studio Bandung, a playground inside the room and the world is managed by Trans Corp. Trans Studio Bandung is a very magnificent sights and very appropriate for the holiday. Trans Studio Bandung is not only tourist rides in the largest room in Indonesia but also the world. Trans Studio Bandung has an area of 4.2 hectares arena, doubled compared to Trans Studio in Makassar which has an area of only 2.4 hectares. In the Trans Studio Bandung is available 20 rides and diverse forms of entertainment that are within 3 large areas with unique and has a different theme.

Trans Studio Bandung as a place of amusement (theme park) and recreation which opened in mid-June 2011 and also requires the right strategy to increase public awareness of its products. The trick is to offer a variety of advantages and uniqueness Trans Studio Bandung through promotional activity. Promotions are done through electronic media, print media, internet media, and other mediamedia is expected to attract audiences and also get more attention from the public. However, the manager continues to innovate in terms of service. This is because there are many visitors who do not understand the various services provided facilities manager.

Dimensions of service quality are implemented properly can be a key factor that has implications for the success of a tourism area as it can create tourist satisfaction. Perceived satisfaction can drive to visit again giving rise to a positive thing for the success of the manager. Business if it is able to provide good service so Tourists feel satisfied. With this, Tourists can foster loyalty. Foster loyalty Tourists must start with the manager demanding loyal employees in the work and the responsibility for the creation of optimal service.

An increasing number of Tourists on the Trans Studio Bandung must be followed by an increase in the quality of services offered by service providers. This is based on research Waguespack, et al (2007) and Tidtichumrernporn, et al (2010) that the service quality of a service can not be ruled out, because it can increase the competitive advantage in obtaining satisfaction of the consumer and the consumer. Quality of service or the quality of service offered by the manager of Trans Studio Bandung is still not fully optimized. Zakaria (2010), said that the good quality of service is required by the consumer. Not optimal quality of those services that keep the quality of service of the Trans Studio Bandung satisfied or very satisfied in the minds of consumers.

Customer satisfaction is a kind of emotional reflection for trade. It depends on the degree of fulfillment of the expected product or service benefits, as well as the degree of consistency of expectations and actual results. This problem can be solved by the manager of Trans Studio Bandung, where the commitment to quality 
customer service that is based on the main prerequisites for business success, especially in the service industry. The success of the service production process is dependent on the customer's assessment of service quality of a service (Kaderi and Diahmarissa, 2003).

If satisfaction rating has been achieved, then the next task of the management is the manager of Trans Studio Bandung obtains and maintains Tourist loyalty. All businesses that provide services largely depend on how to build long-term relationships that concentrate on maintaining customer loyalty (Rousan, 2010). Loyalty rating greatly affect the initial goals established Trans Studio Bandung, because loyalty is one of the key factors to the success of an enterprise (Singh, 2006). Loyalty can be formed from a sense of satisfaction that has previously been created in the minds of consumers (Qin Hong, 2008). This phenomenon shows that the quality of service to give effect to the satisfaction of which will have implications for consumer loyalty.

\section{Problem Formulation}

Based on the problems identified in the background of the problem outlined above, then the problem can be formulated in this study as follows:

1. How does the influence of service quality and tourist satisfaction in Tourism Regions Integrated Trans Studio Bandung?

2. How does the quality of service to Tourists loyalty in Tourism Regions Integrated Trans Studio Bandung?

3. How does the effect of satisfaction on loyalty Tourists in Tourism Regions Integrated Trans Studio Bandung

\subsection{Services}

\section{Review Of Theory}

Services as a process rather than a product, whereby a process involving input and transform as output. Two categories that has been processed by the service are people and objects. While the definition of services according to Berry and Zeithaml Bitner dikutif that dikutif Arif (2007: 11). "Services is considered as a process of action and appearance." Tjiptono Fandy (2002: 6) defines. "The service is any act or acts that may be offered by one party to the other party, which is essentially Intangible (intangible)."

According Creep (2001) which dikutif Arif (2007: 12), the service itself has many meanings, from personal services to service as a product. So basically all the services of an economic activity that results are not a product in physical form or construction, which is usually consumed at the same time with the resulting time and provide added value, such as convenience, amusement, pleasure, health or solving problems faced by consumers .

Valarie A. and Mary Jo Bitner Zethaml defines services as all the economic activity that results are not a product in physical form or construction, which is usually consumed at the same time with the resulting time and provide added value (such as convenience, amusement, pleasure, or health), or a solution to the problems faced by consumers.

In general, services have some special characteristics that are different from the goods. Services have a major influence in marketing, which is intangible, can not be separated between production and consumption processes, which have a variable rate tiggi, can not be stored and does not cause an ownership. (Parasuraman, Zeithaml and Berry, 1985) which dikutif Arif (2007: 19).

Philip Kotler (2012: 112-115) translated by Teguh Hendra, Many A.Rusli and Benjamin, mentioned that in general the service has four major characteristics that greatly affect the design of marketing programs include:intangibility, inseparability, variability, and perishabity.

a. Intangibility, as intangible services. Usually subjectively perceived service and when the service described by the customer, such as the expression of thoughts, beliefs, feelings, and benchmark security is in use. The core of the service is the lack of the phenomenon itself embodies. Because of the high degree of ketidakberwujudannya it difficult in the evaluation of services by the customer.

b. Inseparability, usually service is produced and consumed simultaneously. This does not apply to physical goods, which are manufactured, stored as inventory, distributed through many sellers, and consumed later.If person providing the service, pemyediaan is part of the services.

c. Variability, because it depends on who is giving it, when and where it provides, services vary widely. In addition, due to the production and delivery process is done by humans. Because humans have a nature that is not consistent so that the delivery of a service is not necessarily the same for each customer.

d. Perishabity, services can not be stored. Services are highly perishable nature (perishability) that will not be a problem if demand continues to run smoothly. If the company fluctuates, service firms face a complex problem. 


\subsection{Quality of Service}

Quality of service is an overview of the implementation of the service run as specified. For example, the use of relatively fast, relatively fast rate of completion of work and quality of work. This indicates, that the quality of service means that there is effectiveness and efficiency of the activities created in the service.

According Tjiptono (2005: 110): "the quality of services or quality of service is defined as a dynamic state associated with products, services, human resources, processes and environments that meet or exceed expectations." Quality of service is a comparison between what customers expect with performance services they receive. Models based on the understanding that the quality of customer service is a form of perception for services received. The difference between customer expectations on the performance of the services in general the performance is acceptable will deploy customer perceptions of the quality of certain services (Lieu, 2008: $87)$.

Further Tjiptono et. al. (2008: 82) argues "reflects the service quality of the comparison between the level of service delivered the company than customer expectations. Service quality is realized through fulfilling the needs and desires of customers and delivery accuracy in offset or exceed customer expectations. Hope customers can be three standards, namely:

a. Will expectation, the level of performance that is anticipated or expected customer will receive, based on all the information he knows.

$b$. Should expectation, the level of performance that is considered appropriate that the customer received. Usually the demands of what should have received much greater than what is expected to be accepted.

c. Ideal expectation, the optimum level of performance that is expected or acceptable best customers.

\subsection{Customer Satisfaction}

Customer satisfaction is the customer's evaluation of the products or services received are in accordance with the needs and expectations of customers. Failure to reconcile the needs and expectations assumed as dissatisfaction with a product or service. "Zeithaml et. al. (2003: 43). Customer satisfaction is the evaluation of the chosen alternative purnabeli wherein at least equal atu exceed customer expectations, while dissatisfaction arises when the results (outcomes) did not meet expectations. "Engel et. al. (2000: 241).

Further it is said that customer satisfaction is influenced by the characteristics of specific products or services and the perception of quality. In addition, customer satisfaction is also influenced by the emotional response of customers and customer attributes.

Meanwhile, according to Kotler and Keller defines satisfaction as "Satisfaction is a person's feelings of pleasure or disappointment of the comparison of the performance of the products or services received with expectations". Kotler and Keller, (2009: 87). Satisfaction is a function of perception or impression of the performance and expectations. The expectations of the customers affected by the purchase of their previous experience, the advice of friends and colleagues, and an appointment or information marketers and competitors.

Hope a customer for goods or services, it is influenced by four (4) factors, namely, the information by word of mouth, personal needs, past experiences, as well as communication with external parties. In building customer satisfaction according to Kotler and Keller, one of which can be achieved through quality of service. Perfect quality of service is a form of service delivery provided by a customer exceed customer expectations, this involves giving satisfaction to customers through the buying process since from the beginning to the postpurchase. Or in other words, is the customer service process all customer contact activities to facilitate the proper parties in the company and get the service, response, and quick problem resolution and satisfactory.

A satisfied customer is a customer who felt getting the value from the suppliers, manufacturers or service providers. This value can be derived from the products, services, systems and something that is emotion. This value can be a quality product, the price is attractive and pleasant service. A satisfied customer is a customer who will share their satisfaction with the manufacturer or provider. Sometimes, satisfied customers will share the feeling and experience to other customers (word of mouth). It will be a reference for the company concerned. Therefore, both the customer and the manufacturer, will equally benefit occurs when satisfaction. With this relationship, it is clear that customer satisfaction should be one of the goals of each company.

\subsection{Customer Loyalty}

The term loyalty has often played by marketing experts and business practitioners, loyalty is a concept that seems easy to talk about in the context of everyday life, but it becomes more difficult when analyzed meaning. According Usmara (2008: 122) Loyalty is Mendalan commitment to repurchase or re-patronize a product or service that is selected in the future, by buying the same brand over and over again, despite situational influences and marketing efforts, potentially causing behavior to move.

According to Oliver (1996: 123) as written by Ruth Hurriyati 2010 defines customer loyalty as follows: "Customer loyalty is deeply held commitment to rebuy or repatronize a preferred product or service 
consistenlylate the future, despite situational influences and marketing effort of having the potential to cause switching behavior ".

The point here is consumer loyalty survives in depth customer commitment to re-purchase the product either goods or services consistently in the future despite the potential marketing efforts influence the situation changing behavior.

Loyalty according Kertajaya in Hurriyanti (2005: 35) loyalty in The Oxford English Dictionary is "a strong feeling of support, and allegiance; a person showing firm and constant support". From the definition, there is a strong word that means feeling the depth of human feelings to something, such as family or friends. This feeling is the key element that determines customer loyalty.

According to Kotler and Keller in the Oliver (2012: 149) is a customer loyalty to survive deep commitment to re-purchase or re-subscribe to the selected product or service consistently in the future, although the influence of the situation and the marketing efforts have the potential to cause changes behavior. From the definition it can be said that Oliver loyal customers have some sort of fanaticism that is relatively permanent in the long term for a product/service or a company that has become the choice.

\subsection{Framework}

Based on the literature review that formed from the theories that have been proposed in the above chart, it can be described framework or paradigm of research as follows:

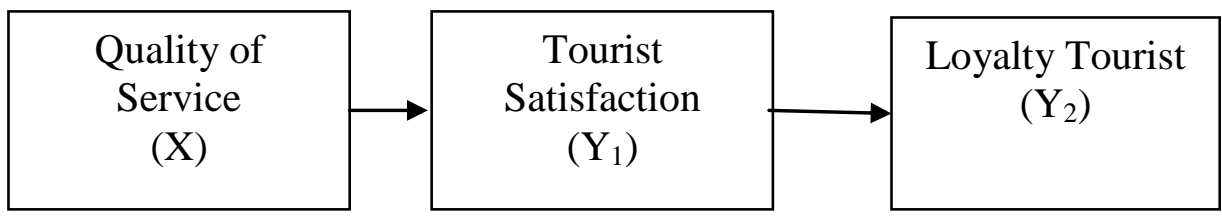

Figure 1. Framework

\subsection{Methods Used}

\section{Research Methods}

This study uses explanatory survey, as it will explain the relationship between the variables studied. While the type of relationship between the variables used in this study are causality independent variable / independent variables affect depeden variable/dependent variable (Sugiyono, 2006: 39). Explanatory research refers to the hypothesis that will be tested against the phenomena that occur. This study is based on crosssectional bersipat time coverage that reflects a description of a situation and phenomena that occur at a given time (Sekaran, 2003: 73). Referring to the purpose of the research to be done is to determine and examine more deeply the research variables that will be examined is this study is descriptive and verification. Descriptive research is research that aims to get a picture or description of the variables studied. While the verification study was to determine the relationship between variables through a hypothesis testing based on the data in the field.

\subsection{Data Collection Techniques}

To obtain the data required primary or secondary, data collection techniques by the author are:

\section{a. Questionnaire}

Author distributing questionnaires, distributed to the respondents made in the form of the questions that are closed and each subject was asked to choose one of the alternative answers were determined. Before the questionnaires were distributed done some testing beforehand, ie testing the validity and reliability testing.

\section{b. Documentation}

This method is used to obtain secondary data by means of studying the archives or records, books including the geography, demographics, and form of writing that has to do with this research. This data is used to supplement the data obtained through interviews.

\subsection{Data Analysis}

Analysis of the data used in the study is the method of regression analysis. In a regression analysis will be developed Estimating equation (regression equation) is a mathematical formula that is looking for the value of the dependent variable independent of known value. Regression analysis is used primarily for forecasting, which in this model there is a dependent variable and independent variables. In practice, regression analyses often distinguish between simple regression and multiple regressions. Called simple regression if there is only one independent variable, while the so-called multiple regression, if there is more than one independent variable. 
In this study there were 2 (a) dependent variable, namely the satisfaction and loyalty of Tourists, and one independent variable, namely the quality of service that basis, the method of analysis used is simple and multiple regression, the equation can be expressed as follows:

$\mathrm{Y}_{1}=\alpha+\beta \mathrm{X}$

$Y_{2}=\alpha+\beta_{1} X+\beta_{2} Y_{1}$

Information:

$Y_{2}=$ Loyalty tourist

$\mathrm{Y}_{1}=$ Touristsatisfaction

$\mathrm{X}=$ Quality tourist

$\beta_{1}, \beta_{2}=$ Regressioncoefficient

$\alpha=$ Regressionconstants

\subsection{General Description Trans Studio Bandung}

\section{Results And Discussion}

Trans Studio Theme Park, Trans Studio Bandung Indoor themepark is the second in Indonesia after the Makassar. Trans Studio Bandung is more spectacular and more powerful than the Trans Studio in Makassar, but both still have its own uniqueness that makes Trans Studio Bandung is not only the largest in Indonesia is also the world's biggest theme park.

Trans Studio Theme Park presents 20 rides games and various forms of entertainment available in three (3) areas with different themes and unique. The visitors can feel how to be a star in front of the camera and into the - the behind the scenes of the show - favorite shows and TRANS TV TRANS 7, such as Other World, Cruising, Si Bolang, and many other exciting rides.

The admission price in the offer by the Trans Studio Bandung, are: Monday-Friday, Rp. 150.000, - (One hundred and fifty thousand dollars), and Saturday-Sunday or holiday is Rp. 250.000, - (Two hundred and fifty thousand dollars).

Admission ticket valid for the entire vehicle which is provided in the Trans Studio Bandung and attractions as much, or even many times. Trans Studio Bandung admission tickets also use mega cash card, the card price is 10,000, -. With this cash apat mega card used to make all transactions in all the outlets in the Trans Studio Bandung.

\subsection{Results of Descriptive Analysis}

Descriptive analysis in the study is intended to describe the phenomenon of the variables used in this research. The results of the descriptive analysis are as follows:

$a$.

Quality of Service

Frequency of respondents' answers and their scores of the questions on the questionnaire quality of service can be right on the plot-line intervals, showed the following results: 10783

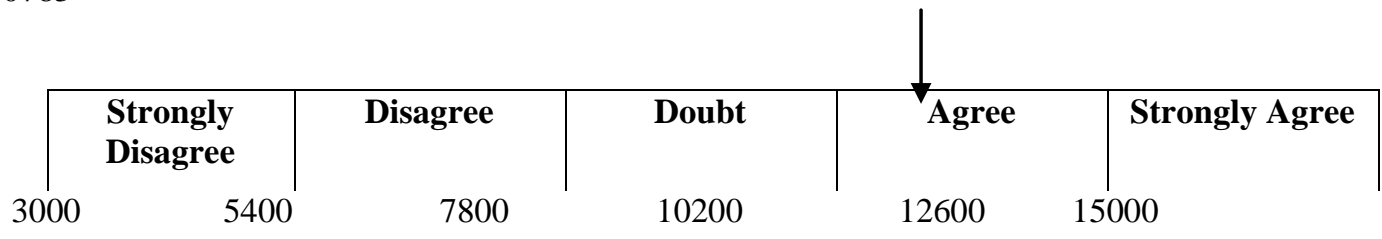

The results of the above intervals provide a general description that the questionnaire quality of service is in the category "Agree". The results of this study revealed that good service quality is very important in a business, considering a business that will provide the best service quality impact on customer satisfaction. Good service quality is formed by aspects, tangible, reliability, responsiveness, assurance and empathy. The results above reflect agreed that all aspects have been disarasa both by tourists. This is due to a variety of existing facilities and infrastructure continue to be developed and improved, including human resources expertise. Because a service can not be seen, can not be kissed and could not be touched, the tangible aspect becomes important as the size of the service. Tourist will use the sense of sight to a given quality of service. Tourist will have the perception that the manager of a tourist area has a good service if parking looks spacious with good security, professional employees, guarantees both safety and so forth. In addition to the physical vehicle, customers will rate the physical appearance of neatness and employees. Distinctive uniforms of employees, has provided a major force in influencing the perception of the customers that they have a good service quality.

b. $\quad$ Tourist satisfaction

Frequency of respondents' answers and their scores of the questions on the questionnaire tourist satisfaction can be right on the plot-line intervals, showed the following results: 
1078

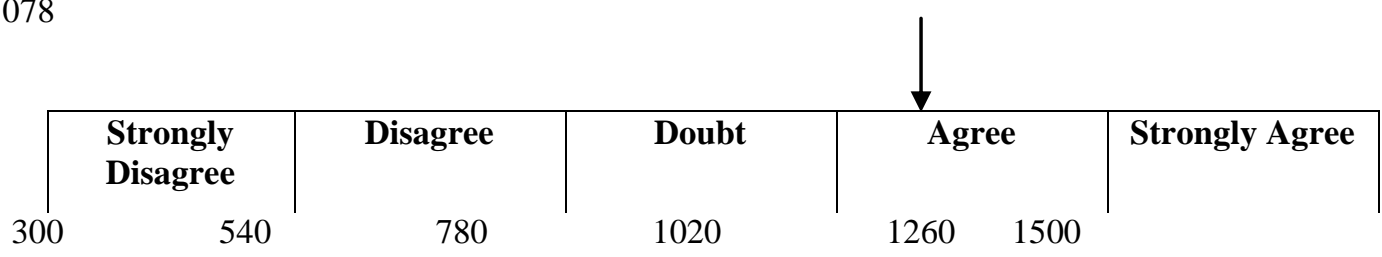

The results of the above intervals provide a general description that tourist satisfaction questionnaires are in the category of "Agree". This means that Tourists overall satisfied with the rides or other facilities provided in the tourist area of Trans Studio Bandung. Satisfaction is a feeling felt by Tourists, when obtaining services provided by the managers. Indicators used to measure satisfaction in this study is based on experience, satisfaction with services and fulfilling the expectations of tourists. Customer satisfaction is a feeling of consumer response to the product or service that has been consumed. In general, satisfaction can be interpreted as a comparison between the results received services or consumer to consumer expectations, service or received the results should at least be equal to the expectations of the consumer, or even surpass.

c. Loyalty Tourist

Frequency of respondents' answers and their scores of the questions on the questionnaire Tourists loyalty can be right on the plot-line intervals, showed the following results:

2183

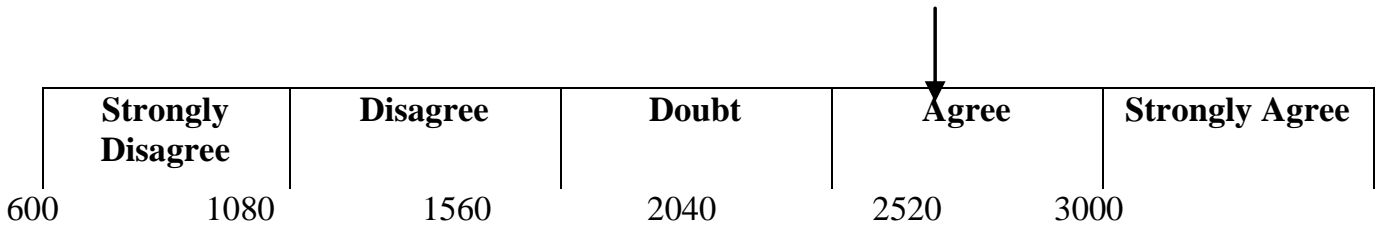

The results of the above intervals provide a general description that Tourist loyalty questionnaire is in the category "Agree". These results indicate that customer loyalty will arise naturally when they are satisfied with the services provided by the service provider. Customer loyalty is closely related to the service and satisfaction they get from the manager of the tourist area. With high loyalty Tourists will always recommend the tourist areas to others, it is a great asset to the company, which is in addition recommend Tourists will always use the products or services, Tourists would be a good spokesperson on other Tourists.

\subsection{Results of analysis verification \\ a. Results of Regression Analysis \\ 1) Simple Linear Regression}

Regression Analysis with SPSS ver 15 for windows intended to analyze the influence of variables on service quality and tourist satisfaction is to see a large coefficient of determination (R Square). In this study, there was 1 (one) dependent variable and one independent variable is the variable quality of service and satisfaction that is independent Tourists. Under these conditions, the method used is regression analysis. From the regression analysis were performed using SPSS help ve.r 15 for windows, if the results of the data may look like Table 1 below:

Table 1. Regression Test Results

\begin{tabular}{|c|c|c|c|c|c|c|}
\hline & \multirow{2}{*}{ Model } & \multicolumn{2}{|c|}{ Unstandardized Coefficients } & \multirow{2}{*}{$\begin{array}{c}\text { Standardized } \\
\text { Coefficients } \\
\text { Beta }\end{array}$} & \multirow[t]{2}{*}{$\mathrm{t}$} & \multirow{2}{*}{ Sig. } \\
\hline & & B & Std. Error & & & \\
\hline \multirow[t]{2}{*}{1} & (Constant) & 38.059 & 4.664 & & 8.160 & .000 \\
\hline & Quality of Service & .997 & .066 & .446 & 4.465 & .006 \\
\hline
\end{tabular}

a Dependent Variable: Tourist satisfaction

Based on the above table, the regression equation in the can is as follows:

$\mathrm{Y}_{1}=38,059+0,997 \mathrm{X}$

Information:

$\mathrm{Y}_{1} \quad=$ Tourist satisfaction

$\mathrm{X} \quad=$ Quality of Service

Simple linear regression equation above between service quality and customer loyalty shows that service quality positively and significantly (real) tourist satisfaction at a significance level $(\alpha=0 \%)$ so that at $\alpha=5 \%$ level of 
service quality and a significant positive effect on satisfaction integrated tourism Tourists Trans Studio Bandung.

\section{2) Multiple Linear Regression}

The results of multiple linear regression analysis with SPSS ver 15 for windows intended to analyze the influence of variables on service quality and satisfaction of tourists, Tourist's loyalty is to see a large coefficient of determination (R Square). In this study, there was 1 (one) dependent variable, ieTourists loyalty, and two independent variables, namely service quality and tourist satisfaction. Under these conditions, the method of analysis used is multiple regressions. From the regression analysis were performed using SPSS ver 15 assistance program for windows which also have been used to test the significance of the individual or the t-test obtained the following table:

Table 2.Regression analysis

\begin{tabular}{|c|c|c|c|c|c|c|}
\hline & \multirow[t]{2}{*}{ Model } & \multicolumn{2}{|c|}{ Unstandardized Coefficients } & $\begin{array}{l}\text { Standardized } \\
\text { Coefficients }\end{array}$ & \multirow{2}{*}{$\mathrm{t}$} & \multirow{2}{*}{ Sig. } \\
\hline & & B & Std. Error & Beta & & \\
\hline \multirow[t]{3}{*}{1} & (Constant) & 10.023 & 1.730 & & 5.793 & .000 \\
\hline & Quality of Service & 279 & .045 & .439 & 3.769 & .000 \\
\hline & Tourist satisfaction & .330 & .043 & .618 & 7.595 & .000 \\
\hline
\end{tabular}

a Dependent Variable: loyalty Tourist

Based on the above table, the regression equation in the can are as follows:

$\mathrm{Y}_{2}=10.023+0,279 \mathrm{X}_{1}+0,330 \mathrm{Y}_{1}$

Information:

$$
\begin{aligned}
\mathrm{Y}_{2}=\text { Loyalty tourist } & \\
\mathrm{Y}_{1} & =\text { Tourist satisfaction } \\
\mathrm{X} & =\text { Quality tourist }
\end{aligned}
$$

Mathematical models of the above equation show that the effect is more dominant than the satisfaction of quality of service to Tourist's loyalty. It was shown from the regression coefficient is 0.330 greater satisfactions than the regression coefficient 0.279 worth of service quality.

\section{b. Hypothesis Testing}

Based on the research paradigm that has been stated previously, this study will examine the hypothesis. To test the hypothesis used statistical tests with multiple regression calculations as quantitative analysis. The results of hypothesis testing based on the results of the analysis that has been presented previously can be described as follows:

\section{1) Effect of Quality of Service to Tourist Satisfaction}

The results of partial significance test (t-test) using SPSS ver 15 for windows can be seen in Table 1 Based on the table above, it can be seen that the value of the probability of its significance or is sig. 0.006 or less than 0.05 or $5 \%$. In addition, based on the results of the analysis diperilehtcount of 4.465 is greater than the value ttable 1,969. Because the sig $<0.05$ and t-test values greater than t-table it is said that the quality of service and a significant positive effect on tourist satisfaction in integrated tourism Trans Studio Bandung. These results agree with research conducted Dabholkaret, al (2000) in Tjiptono (2005) states that service quality has a significant influence on customer satisfaction. Cronin and Taylor (2005) found a strong and positive relationship between service quality and satisfaction.

\section{2) The effect of Service Quality on Loyalty Tourist}

The results of partial significance test (t-test) using SPSS ver 15 for windows can be seen in Table 2 . Based on the table above, it can be seen that the value of the probability of its significance or sig. is 0,000 or less than 0.05 or $5 \%$. In addition, based on the analysis of 3,769 diperilehtcount greater than the value ttabel 1,969. Because the sig $<0.05$ and t-test values greater than $\mathrm{t}$-table it is said that the quality of service and significant positive effect on loyalty Tourists in integrated tourism Trans Studio Bandung. These results support the theory proposed Costabile (2000 in Smith and Wright, 2004) is a customer loyalty form a strong relationship between the consumer and the company, the better the quality of services provided, the customer will be more loyal to the products/services. According to Hill (1997 in Rusdarti, 2004) is a loyalty behavior shown by routine purchases based on the decision-making unit. Furthermore Grifin (1995 in Smith and Wright, 2004) states that a 
consumer into a loyal customer then has to go through several stages including suspects, prospect, prospect disqualified, first-time customer, repeat customer, the client, advocates. Customer loyalty is one chance in a long period of time, where they make a purchase on a regular basis and buying behavior are not made to randomize the (non-random) few units of decisions. In addition, the characteristic of a loyal customer is a person who is immune to the appeal of other products and always provides feedback to the company.

The results of partial significance test (t-test) using SPSS ver 15 for windows can be seen in Table 2 Based on the table above, it can be seen that the value of the probability of its significance or sig. is 0,000 or less than 0.05 or $5 \%$. In addition, based on the results of the analysis diperilehtcount of 7.595 is greater than the value ttable 1,969. Because the sig $<0.05$ and t-test values greater than $\mathrm{t}$-table then said that tourist satisfaction and a significant positive effect on loyalty Tourists in integrated tourism Trans Studio Bandung. These results support the research conducted by Hidayat (2009) declares the results of research done at the bank that customer satisfaction has positive influence on customer loyalty. Palilati (2007) also reinforce the results of research on savings banking customers in South Sulawesi that the level of customer satisfaction over the performance attributes savings are significant and positive effect on customer loyalty to banks.

\section{c.}

\section{Coefficient of Determination}

To measure how far the ability of independent variables in explaining the dependent variable used the coefficient of determination, R2 price. The fundamental flaw using the coefficient of determination is biased against the number of independent variables included in the model. Therefore, many researchers advocate for the use of Adjusted R2 values when evaluating the best regression model. SPSS data processing results are shown in the following table:

Table 3.Coefficient of Determination

\begin{tabular}{c|r|r|r|r}
\hline Model & R & R Square & Adjusted R Square & $\begin{array}{c}\text { Std. Error of the } \\
\text { Estimate }\end{array}$ \\
\hline 1 & $.720(a)$ & .518 & .502 & 3.70151 \\
\hline
\end{tabular}

a Predictors: (Constant), Quality Service, Tourist Satisfaction

Based on the model of the SPSS output display summary or table 3 above, the magnitude of the adjusted $\mathrm{R} 2$ is 0.502 this means that the $50.2 \%$ loyalty Tourists dependent variable can be explained or influenced by the independent variables of service quality and tourist satisfaction, while the remaining $49.8 \%(100 \%-50.2 \%)$ is explained by other causes beyond the research model.

\subsection{Conclusion}

\section{Conclusions And Recommendations}

Based on the formulation of the problem as well as the results of research and discussion, we can conclude the following:

a. Service quality and a significant positive effect on tourist satisfaction in integrated tourism Trans Studio Bandung. That is good service quality can increase the confidence rating on the quality of services offered, with the optimum service quality satisfaction of tourists will increase by itself.

b. Service quality and a significant positive effect on loyalty Tourists in integrated tourism Trans Studio Bandung. This means that service quality also has a strategic role in shaping wisatawa loyalty. A tourist will be loyal to a tourist attraction if these attractions can meet their needs well.

c. Tourist satisfaction and a significant positive effect on loyalty Tourists in integrated tourism Trans Studio Bandung. This means that if a tourist was satisfied with the services received, the loyalty will be formed. Level will affect the degree of satisfaction or loyalty products or services of a person. The more satisfied a tourist with a product or service that is owned by a company, it will be more loyal to the services.

\subsection{Recomendations}

follows:

Based on the above conclusions, the suggestions that can be given by the results of this study are as

a. The manager of Trans Studio Bandung in order to continue to make innovations that is effective and efficient in order to maintain customer loyalty.

b. Trans Studio Bandung manager is expected to improve the quality of services, especially the employees must be able to provide accurate information services, employees must be able to deal with complaints from Tourists perceptive and hours of service must be in accordance with the needs of Tourists. 
c. Future studies are expected to examine more in not limited to the variables that have been studied, but the need for the addition of other variables and are expected to use the object of more extensive research. In addition, further research is expected to develop existing analytical models to get more in-depth results.

\section{References}

[1] A. Usmara, 2008. Human Resource Management Practices: Winning through Orientation and Training. Employees, Yogyakarta: Santusa.

[2] AlidaPalilati, 2007, Affect of Customer Value, Satisfaction to Customer Loyalty Savings Banking in South Sulawesi, Petra Christian University.

[3] Arief. 2007. Service Marketing \& Service Quality, Malang: Bayumedia, Publishing.

[4] Cronin, J.JosephJrdan Steven Taylor, 2005, Measuring Service Quality: Reexamination and Extension, Journal of Marketing.

[5] Engel, James F., et.al. 2000. Consumer Behavior. Translated by F.X. Budiyanto, Consumer Behavior, Sixth edition, First printing, Volume II. Jakarta: BinarupaAksara.

[6] FandyTjiptono, 2002, Marketing strategy, Andy Offset, Yogyakarta

[7] FandyTjiptono, 2008, Strategic Marketing, Andy Offset, Yogyakarta

[8] FandyTjiptono. 2005. Services Marketing, First Edition, Bayu Media Publishing, Malang.

[9] Fujun Lai, Mitch Griffin \& Barry J. Babin. 2009. How quality, value image, and satisfaction create loyalty at a Chinese telecom. Journal of Business Research. 62 (2009) 980-986.

[10] HurriyatiRatih, 2010. Marketing Mix and Consumer Loyalty, Bandung: CV. Alfabeta.

[11] Kaderi, S. danDiahmarissa, T. 2003. AnalisisKualitasPelayananJasaPenerbangan, StudiKasus : Garuda Indonesia kelasEkonomi. JurnalManajemen ITB, 2(10): h; 13-23.

[12] Kotler Philip, dan Gary Amstrong. 2012. Principles Of Marketing, Global Edition, 14 Edition, Pearson Education.

[13] Oliver, R.L., 1996 "A cognitive model of the antecedents and consequences of satisfaction decisions"Journal of Marketing Research, Vol. XVII, November.

[14] Parasuraman, A., Zeithamal, V.A., and Berry, L.L., 2003, "SERVQUAL: A Multiple-Item Scale for Measuring Consumer Perceptions of Service quality."Journal of Retailing, Volume 64, Number 1, spring.

[15] Parasuraman, A., Zeithaml, V.A., \& Berry, L.L, 1985, "A conceptual model of service quality and its implications for future research.”Journal of Marketing, Vol. 49, fall.

[16] Philip Kotler\& Kevin Lane Keller, 2009, Marketing Management, 13th Edition, Volume 1. Jakarta.

[17] Qin. Hong and Victor R. Prybutok. 2008. Determinants of Customer-perceived service quality in fast food restaurants and their relationship to customer satisfaction and behavioral intentions, The Quality Management Journal 15(2): 35

[18] Rousan, Al, M. Ramzidan Mohamed, B. 2010. Customer Loyalty and the Impacts of Service Quality: The Case of Five Star Hotels in Jordan. International Journal of Human and Social Sciences, 5(13): h; 886-892.

[19] Rusdarti, 2004, Effect of Service Quality and Value Service to Customer Loyalty at BPD Bank branch in Semarang, Central Java, Journal of Business Strategy, Vol. 13/ Juli/ 2004, p. 54 - 65

[20] Singh, H. 2006. The Importance of Customer Satisfaction in Relation to Customer Loyalty and Retention.Academy of Marketing Science, 60: h; 193-225.

[21] Smith, Rodney E, and Wright, William F, 2004, "Determinants of Customer Loyalty and Financial Performance"Journal of Management Accounting Research. Vol.16 pg. 183, 23 pgs.

[22] Sugiyono, 2006, Statistics for Research, Alfa Beta, Bandung.

[23] Tidtichumrernporn, T.,Janasak, S., Mujtaba, B.G., Khunsongkiet, P., Duangjai, N. danBhawanantechanon, N. 2010. Measuring the Satisfaction of Domestic and International Tourists toward Lanna Cultural Tourism Products: A Study of Progress in Chiang Mai Walking Street Activities. Journal of Business Studies Quarterly, 1(3): h; 31-52.

[24] Tjiptono, Fandy. 2008. Achieve Service Management Prime Services, Bandung: CV Alfabeta.

[25] Uma Sekaran. 2003. Research Method for Bussiness A Skill Building Approach. Fouth Edition.John Wiley \& Son.

[26] Waguespack, B., Rhoades,D.L. danTiernan, S. 2007. An Investigation into Airline Service Quality Performance between US Legacy Carriers and Their EU Competitors and Partners.Journal of Air Transportation, 12(2): p. 59-71.

[27] Zakaria, Z, Husin, Z.Hj.,Batau, M.F.A. danZakaria, Z. 2010. Service Quality of Malaysian Public Transports: A Case Study in Malaysia. Cross-Cultural Communication, 6(2): p. 84-92. 